\title{
POSŁUGIWANIE BISKUPÓW, PREZBITERÓW I DIAKONÓW W PISMACH OJCÓW KOŚCIOŁA DO V WIEKU
}

W literaturze patrystycznej pierwszych wieków nie ma jednoznacznej terminologii, odnoszącej się do posługiwania we wspólnotach kościelnych. Brak również jasnych tekstów mówiących o relacjach biskup - prezbiter - diakon ${ }^{1}$. Nazewnictwo kościelne, odnoszące się do pełniących posługi we wspólnocie wiernych, odbiega od tego, którym posługiwano się w Grecji i w Rzymie na określenie funkcji związanych z wykonywaniem kultu. W świecie kultury grec-

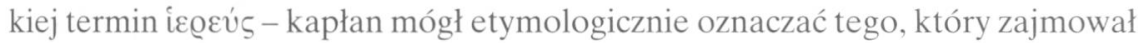
się rzeczami świętymi, związanymi z bóstwami, składaniem ofiar i tłumaczącym znaki przy ich składaniu. W religii greckiej, w sensie szerszym, kapłanem był każdy, kto składał święte ofiary, modlił się za innych i opiekował się przedmiotami poświęconymi bóstwu. W sensie zaś właściwym była nim osoba pełniąca służbę w sanktuarium albo jakiś określony kult. Kapłan był pośrednikiem między ludźmi i bóstwem. W Grecji znane były trzy rodzaje czynności wykonywanych przez kapłanów: diakonalne - troska o obiekty sakralne (o ich czystość i bezpieczeństwo, pilnowanie rzeczy poświęconych bóstwu); administracyjne - troska o majątek (ruchomy i nieruchomy), rozbudowa i konserwacja świątyni; liturgiczne - głównie składanie ofiar (rytualne uśmiercanie ofiar, wyjmowanie $\mathrm{z}$ nich wnętrzności, wróżby $\mathrm{z}$ wątroby, akt poświęcenia ofiary i modlitwa ofiarnicza). Kapłani mieli także nadzór nad obowiązującymi rytuałami przy składaniu ofiar indywidualnych ${ }^{2}$. Kapłanami byli zwykle mężczyźni, chociaż przy bóstwach żeńskich występowały w tej roli także kobiety.

Łaciński termin sacerdos oznaczał tego, kto zajmował się świętymi darami. W Rzymie byli indywidualni kapłani, ale również zespoły kapłanów związanych z określonym kultem, zrzeszone w kolegiach i sodalicjach ${ }^{3}$. Był także

\footnotetext{
${ }^{1}$ Por. J. Pałucki, Biskup - prezbiter - diakon w refleksji Ojców Kościoła, RT 48 (2001) z. 2, 34.

2 Por. R. Popowski, Kapłaństwo w starożytnym świecie grecko-rzymskim. VoxP 13-15 (1993$1995)$ z. 24-29, 30-31.

Por. H. Kowalski, Kapłani i kolegia kaptańskie w Rzymie w I wieku przed Chrystusem, VoxP 13-15 (1993-1995) z. 24-29, 35-47.
} 
Pontifex maximus jako opiekun państwowej religii i kierujący publicznym kultem. Tzw. kapłaństwo państwowe (sacerdotes publici populi Romani) obowiązywało do końca życia. Pomocnikami kapłanów byli słudzy, określani jako apparitores, calatores, cultrarii ${ }^{4}$. Kapłani rzymscy mieli liczne przywileje, jak immunitet i specjalne miejsca na igrzyskach oraz zwolnienie od ciężarów publicznych, takich jak podatki i służba wojskowa. Zarówno kapłani greccy, jak i rzymscy byli jedynie ,,strażnikami rytuału, a nie doktryny ani etyki”. U Rzymian funkcje kapłańskie pełnił także pater familias, konsul, ale oni nie należeli do sacerdotes publici populi Romani.

Ani u Greków, ani u Rzymian nie było jednak odrębnego stanu kapłańskiego, lecz jedynie funkcja kapłana ${ }^{6}$. Kapłanem zostawało się przez wybór lub losowanie spośród osób zdolnych do urzędów państwowych. Wybrany na kapłana pełnił funkcję zwykle przez jeden rok, czasem jednak dłużej. Przy sprawowaniu funkcji ubierał się w długą szatę koloru białego, a także purpurowego lub szafranowego. Od kapłanów wymagano także zewnętrznej schludności i czystości ciała. Kapłan składający ofiarę miał również prawo do części mięsa, oliwy, wina, miodu składanych w ofierze oraz do udziału w dobrach poświęconych danemu bóstwu?

W czasach Kościoła apostolskiego istniały już różne urzędy i posługi, ale nie było jeszcze hierarchii władzy, ani nie wiadomo o tym, by prezbiterzy podlegali biskupom. Trudno także znaleźć teksty mówiące o relacji biskup - prezbiter -

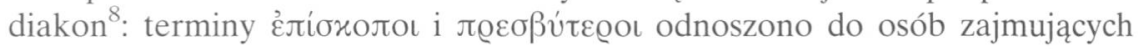
kierownicze stanowiska we wspólnocie. Nie ma też świadectw o istnieniu urzędu kapłańskiego. Apostołowie nie pojmowali swoich funkcji jako czynności kultycznych, nie nazywali siebie kapłanami (iع@eĩs), lecz pełnili „diakonię” (Dz 1, 17 i 25; 2Kor 4, 1). Ich urząd polegał na pośredniczeniu w zastępstwie Jezusa Chrystusa między Bogiem i ludźmi ${ }^{9}$.

W pismach Ojców Kościoła nie ma jednoznacznej terminologii określającej posługiwanie w Kościele ${ }^{10}$. Według A. Hammana, w liście Klemensa Rzym-

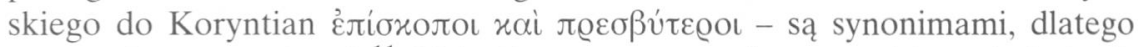
występują tam zamiennie ${ }^{11}$. U św. Ireneusza mowa jest o prezbiterach, których

${ }^{4}$ Por. Popowski, Kapłaństwo w starożytnym świecie grecko-rzymskim, s. 33.

${ }^{5}$ Por. tamże, s. 34

${ }^{6}$ Por. tamże, s. 29.

7 Por. tamże, s. 32 .

${ }^{8}$ Por. Pałucki, Biskup - prezbiter - diakon, s. 34.

9 Por. T. Penar, Chrześcijańskie kaptaństwo urzędowe w świetle Nowego Testamentu, SPelp 14 (1983) 237-238; zob. W. Schenk, Liturgia sakramentów świętych, cz. 2, Lublin 1964, 86-98; A. Faivre, Naissance d'une hiérarchie. Les premières étapes du cursus clérical, Paris 1977.

10 Por. A. Houssieu - J. Mondet, Le Sacerdoce du Christ et des serviteurs selon les Pères de l'Église, Louvain 1990; E. Stanula, Patrystyczna literatura o kaptaństwie (Przegląd bibliograficzny), VoxP 13-15 (1993-1995) z. 24-29, 49-58.

11 Por. A. Hamman, Kapłan w II wieku, w: Kapłaństwo (Communio 3), Poznań 1988 s. 48. 
należy słuchać, gdyż posiadają sukcesję apostolską, przynależąc do episkopa$\mathrm{tu}^{12}$. W II wieku termin $\pi \varrho \varepsilon \sigma \beta u ́ \tau \varepsilon \varrho$ może oznaczać zarówno biskupa, jak i prezbitera (w obecnym rozumieniu), ale w tym czasie nie spotyka się słowa

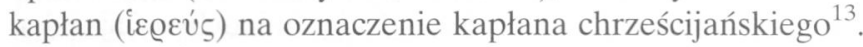

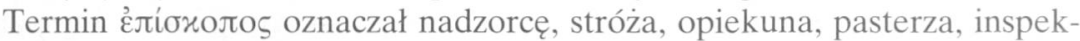
tora czuwającego nad społecznością, kaznodzieję wędrownego a nawet bóstwo patronujące miastu, patrona, stróża świątynnego lub kapłana rzymskiego (por. $2 \mathrm{Krl} 12,11 ; 2 \mathrm{Krn} 34,12$ i 17). Początkowo jego znaczenie było bardzo szerokie

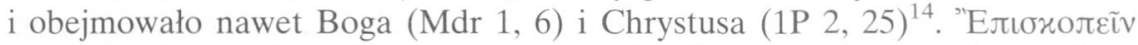

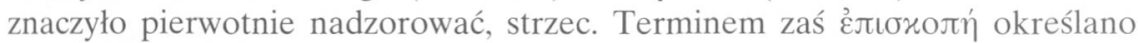
funkcję tego, który czuwa i przewodniczy wspólnocie, aby dobrze funkcjonowała. Biskup powinien być podobny do ojca rodziny dobrze zarządzającego domem, bo zarządza Kościołem jako domem Bożym (1Tm 3, 5). Od IV wieku znany był już podział kleru na dwie grupy: clerici inferioris ordinis i primi clerici lub superioris ordinis: biskupi, prezbiterzy i diakoni. Jednak terminologia ta nie jest jeszcze jednoznaczna. W VI wieku na Zachodzie do kleru zaliczano także ostiariuszy, lektorów, egzorcystów, akolitów i subdiakonów (św. Izydor) ${ }^{15}$. Od poł. IV aż do VI wieku sacerdos oznacza głównie biskupa, czasem także prezbitera; terminologia jest jeszcze płynna. W XI wieku sacerdos to zwykle prezbiter, ale już także biskup ${ }^{16}$.

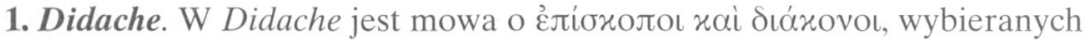
przez wspólnotę, nazywanych także prorokami i nauczycielami. Ich posługiwanie określane jest jako $\lambda \varepsilon ı \tau o v Q \gamma i \alpha$ i jest różne od innych posług pełnionych przez proroków i doktorów, którzy głównie zajmowali się ewangelizacją. Biskup kierował wspólnotą i przewodniczył Eucharystii, a diakon służył mu pomocą: „Wybierzcie sobie biskupów i diakonów godnych Pana, ludzi cichych, spokojnych, bezinteresownych, wiarygodnych i wypróbowanych. Oni bowiem pełnią u was posługę proroków i nauczycieli. Nie gardźcie więc nimi, gdyż należy im się wśród was to samo poważanie, co u proroków i nauczycieli" ${ }^{17}$. Zadaniem apostołów i proroków było nauczanie i utwierdzanie wspólnot już istniejących $^{18}$. Posługiwanie określane jako $\lambda \varepsilon \iota \tau o v \varrho \gamma i \alpha$ mieli pełnić wybrani

zob. też A. Lemaire, Les ministères aux origines de l'Église, Paris 1971, 145-151; Cz. Bartnik, Kościót Jezusa Chrystusa, Wrocław 1982, 220.

12 Por. Irenaeus, Adversus haereses IV 16, 2.

13 Por. B. Częsz, Kapłaństwo chrześcijańskie w II wieku, VoxP 13-15 (1993-1995) z. 24-29, 69-72.

${ }^{14}$ Por. Bartnik, Kościót Jezusa Chrystusa, s. 219-220.

15 Por. Schenk, Liturgia sakramentów świętych, s. 88.

${ }^{16}$ Por. H. Wójtowicz, Terminologia kaptańska w literaturze wczesnochrześcijańskiej, VoxP 13-15 (1993-1995) z. 24-29, 63-66; tenże, Terminologia kapłańska u Tertuliana, tamże, s. 77-87; zob. J. Colson, Les fonctions ecclésiales aux origines de l'Église, Paris 1956.

17 Didache 15, 1, SCh 248bis, 192, thum. A. Świderkówna, BOK 10, 40.

18 Por. tamze 11, 4-6. 
w Kościołach biskupi i diakoni. Nie ma wzmianki o prezbiterach, lecz akcent położony jest na prorokach i nauczycielach, oni także mogli sprawować Eu-

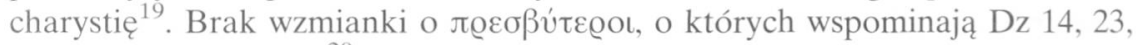
wyjaśnia A. Hamman ${ }^{20}$, powołując się na dwie tradycje: judeochrześcijańską,

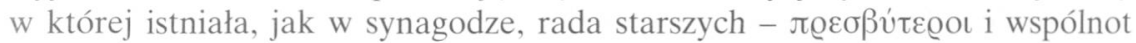
powstałych z nawróconych pogan, w których nawiązywano do słownictwa administracji cywilnej: biskup i diakon ${ }^{21}$. Pasterz Hermasa mówi o ministri Ecclesiae w sensie kolegialnym, ale też o jednym, który jest primus i utrzymuje kontakty z innymi Kościołami. Poleca odczytanie listu „wobec prezbiterów, stojących na czele Kościoła"22.

2. Klemens Rzymski († 101). Klemens, biskup Rzymu, w Liście do Koryntian wzywa do posłuszeństwa prezbiterom ${ }^{23}$. Upomina Koryntian za wyrzucenie prezbiterów z miasta:

„I niemały byłby to błąd pozbawić godności biskupiej tych, co składają Bogu ofiary w nieskazitelnej pobożności" ${ }^{24}$.

Kim byli ci prezbiterzy? „Termin presbyter - starszy może być tu wspólnym określeniem dla biskupa, prezbitera w naszym rozumieniu i diakona" ${ }^{25}$. Prezbiterzy byli ustanawiani „za zgodą całego Kościoła”. Klemens piętnuje postępowanie części wiernych, którzy przemocą usunęli członków hierarchii i wybrali nowych. Pisze, że „Kościół w Koryncie przez jedną czy dwie osoby buntuje się przeciw swym prezbiterom" 26 . Bunt ten doprowadził do pozbawienia ich biskupstwa ${ }^{27}$. Chodziło o sprzeciw nie wobec samego urzędu kościelnego jako takiego, ale o brak akceptacji konkretnych osób. Być może spierano się o to, czy członkowie hierarchii powołani przez gminę mają pełnić swoje funkcje dożywotnio, czy tylko czasowo. Klemens stał na stanowisku, że ich posługiwanie jest trwałe. Powołuje się na Apostołów, którzy „nauczając po różnych krajach wybierali ludzi wypróbowanych duchem i ustanawiali ich biskupami

${ }^{19}$ Por. Pałucki, Biskup - prezbiter - diakon, s. 35; Lemaire, Les ministères aux origines, S. $139-151$.

${ }^{20}$ Por. Hamman, Il sacerdote nel secondo secolo, s. 17.

21 Por. tamże.

22 Hermas, Pastor. Visio II 4, 3, SCh 53bis, 96, tłum. A. Świderkówna, BOK 10, 216; Lemaire, Les ministères aux origines, s. 153-164.

${ }^{23}$ Por. Epistola ad Corinthios 57, 1; zob. J. Ihnatowicz, Dlaczego prezbiter nie może udzielać święceñ? Biskup i prezbiter w pierwotnym Kościele, KiST 2 (2003) 213-232; tenże, Biskup widzialny i biskup niewidzialny. Urząd biskupi w teologii św. Ignacego z Antiochii, w: In vinculo communionis, red. K. Gurda - T. Gacia, Kielce 1999, 65-73.

${ }^{24}$ Epistola ad Corinthios 44, 4, SCh 167, 172, tłum. A. Świderkówna, BOK 10, 71.

25 Pałucki, Biskup - prezbiter - diakon, s. 36.

26 Epistola ad Corinthios 47, 6, SCh 167, 178, BOK 10, 72.

27 Por. tamże 44, 5. 
i diakonami dla przyszłych wierzących”. Ten sposób postępowania ma być stały w Kościele. Apostołowie „później dodali zasadę, że kiedy oni umrą, inni wy-

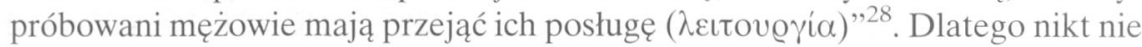
ma prawa usuwać z tego urzędu tych, którzy zostali ustanowieni przez Apostołów, albo ich następców za zgodą całego Kościoła, jeśli ci ludzie służyli owczarni Chrystusowej bez zarzutu ${ }^{29}$. Ich autorytet pochodzi nie od wspólnoty, lecz od Boga, przez sukcesję apostolską. Biskupi służą Kościołowi i składają ofiarę, czyli pełnią funkcje pasterzy i kapłanów. Jeśli św. Klemens pisze o prezbiterach, to jako o nowej instytucji.

Terminu „apostoł” Klemens używa jedynie na określenie Dwunastu i św. Pawła. Prezbiterzy raczej nie byli następcami Apostołów, lecz stali na czele lokalnych wspólnot od nich zależnych, lub później ustanowionych przez nich biskupów np. Tymoteusza i Tytusa. Ci z kolei ustanawiali lokalnych prezbiterów-biskupów. Taką praktykę potwierdzają Listy pasterskie.

Klemens Rzymski Jezusa określa terminami: arcykapłan, przewodnik, po-

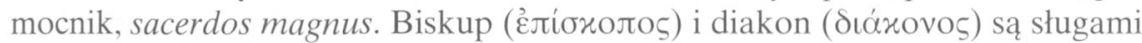
Ewangelii. Według niego sam Bóg ustanowił porządek i hierarchię w Kościele. Każdy powinien troszczyć się o to, aby „podobać się Bogu, tam gdzie go postawiono [...] nie przekraczając reguł określających jego miejsce w służbie

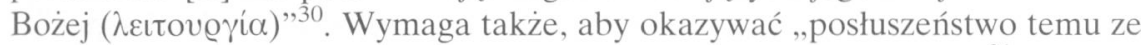
swoich bliźnich, który został obdarzony stosownym charyzmatem"31. Zróżnicowanie posługiwania w Kościele wynika z posiadania różnych charyzmatów. Z woli Bożej charyzmat ten otrzymuje się przez nałożenie rąk (por. 1Tm 4, 14; 2Tm 1,6).

Biskup Rzymu nie podaje, jakie konkretne zadania wypełniali prezbiterzy wspominając jedynie, że służą „Bożej owczarni” i składają Bogu dary $(\delta \tilde{\omega} \varrho \alpha)^{32}$. Służba ta polegała na pomocy w trwaniu w wierze i w tradycji apostolskiej oraz prawdziwej nauce. Tak jak w Tt 1, 9 i 1Tm 5, 17 - mają głosić zdrową naukę, upominać i przekonywać opornych. Odnośnie do składania darów, zwraca się

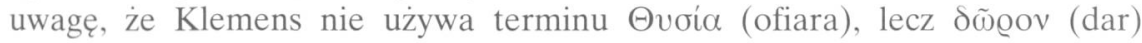
w znaczeniu Rz 12, 1 jako ofiara świętego życia. Może chodzić również o dary składane w czasie Eucharystii dla ubogich, dary ofiarne dla Eucharystii lub nawet jej sprawowanie.

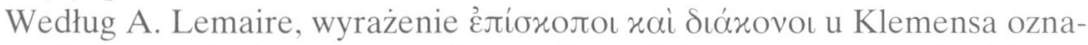
cza ogólnie tych, którzy są na czele wspólnoty jako jej pasterze: chodzi o te same osoby, które są także nazywane $\pi \varrho \varepsilon \sigma \beta u ́ \tau \varepsilon \varrho o \iota^{33}$. Klemens używa terminu

\footnotetext{
28 Tamże 42, 2-3, SCh 167, 168, BOK 10, 70.

${ }^{29}$ Por. tamże $44,3$.

30 Tamże 41, 1, SCh 167, 166, BOK 10, 69.

31 Tamze 38, 1, SCh 167,164, BOK 10, 68.

${ }^{32}$ Tamże 44, 3-4, SCh 167, 172, BOK 10, 71.

${ }^{33}$ Por. Lemaire, Les ministères aux origines, s. 150.
} 


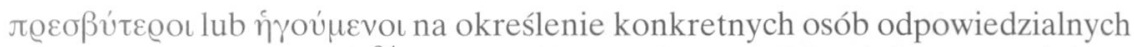
za wspólnotę w Koryncie ${ }^{34}$. Do prezbiterów $(1 \mathrm{Tm} 5,17)$ należy przewodniczenie i nauczanie, dlatego trzeba ich słuchać (por. 1P 5, 5; 1 Kor 16, 16), szanować i cenić.

3. Ignacy Antiocheński († 107). Ignacy Antiocheński przedstawił nie tylko pewną koncepcję Kościoła, ale także rolę i zadania biskupów oraz prezbiterów. Jako pierwszy używa nazwy „Kościół katolicki” w znaczeniu całego ludu Bożego złączonego z Chrystusem: „,gdziekolwiek jest Chrystus, tam też jest Kościół katolicki”"35. Wzoruje się na Kościele jerozolimskim, kierowanym przez Piotra i Jakuba. Ignacy ukazuje już hierarchię Kościoła złożoną z trzech stopni: biskupów, prezbiterów i diakonów (jest to połączenie dwóch tradycji). „Biskupi reprezentują autorytet Boga Ojca, prezbiterzy grono apostolskie, diakoni zaś pełnią funkcję służebną Chrystusa"36. Biskupa wybiera się spośród prezbiterów. Jest on głową Kościoła lokalnego, który obejmuje jedno miasto i chrześcijan zjednoczonych we wspólnocie wiary. Biskup jest obrazem Boga Ojca, prezbiterium senatem biskupa lub kolegium Apostołów, diakoni zaś służą na wzór Chrystusa $^{37}$. Ignacy kładzie duży nacisk na sukcesję apostolską, stanowiącą gwarancję czystości wiary. Ci, którzy zarządzają Kościołem są „pewnymi przewodnikami w wierze, gwarantem poprawności, ważności chrztu i Eucharystii" ${ }^{38}$.

Posługa biskupa jest kontynuacją posługiwania Apostołów. Biskup w Kościele jest włodarzem Chrystusa, którego należy przyjąć i słuchać jak samego Pana: on wiernym zastępuje Boga Ojca niewidzialnego - biskupa wszystkich wierzących ${ }^{39}$. Działalność i władza biskupa dotyczy trzech dziedzin: przepowiadania, pasterzowania i liturgii. Przez niego Bóg nadal prowadzi zbawcze działanie wobec ludzi w Kościele: całe posługiwanie biskupa jest służbą zbawienia. Głównym jego obowiązkiem jest głoszenie słowa Bożego. Ma także pomagać i czuwać nad tym, aby wierni postępowali ,zgodnie z myślą Bożą"40, a także zgodnie z myślą biskupa. Biskup zaś naucza nie tylko słowem, ale także całym swoim życiem i postępowaniem. Według Ignacego biskup jest w centrum Kościoła, prezbiterzy są jakby jego koroną i senatem. Biskup jest jeden i razem z nim działa kolegium prezbiterów. Podkreśla, że tak jest w całym Kościele, bo biskupi ustanawiani są aż po krańce świata ${ }^{41}$. Jest on gwarantem jedności

34 Por. tamże, s. 147-148.

35 Epistola ad Smyrnenses 8, 2, SCh 10, 138, tłum. A. Świderkówna, BOK 10, 138.

36 Por. Pałucki, Biskup - prezbiter - diakon s. 38; Lemaire, Les ministères aux origines, s. 165 174.

37 Por. Ihnatowicz, Biskup widzialny i biskup niewidzialny, s. 65-73.

38 Por. Pałucki, Biskup - prezbiter - diakon, s. 36.

39 Por. Epistola ad Ephesios 6, 1.

40 Tamże 3, 2, SCh 10, 60, BOK 10, 114.

41 Por. tamże. 
Kościoła, tak jak jest jeden Bóg, jeden Chrystus, jeden ołtarz i jedna Eucharystia, jeden Duch i jedno Ciało, jedna wiara i miłość, tak też jest jeden biskup na czele Kościoła i prezbiterium ${ }^{42}$. Ignacy upomina wiernych, aby trwali nie tylko przy biskupie, ale także przy prezbiterach i diakonach ${ }^{43}$ i okazywali posłuszeństwo biskupowi i prezbiterom ${ }^{44}$.

Biskup jako pasterz pełni przede wszystkim rolę jednoczącą we wspólnocie wierzących; jemu powinni być poddani prezbiterzy i diakoni, do niego należy też przewodniczenie Eucharystii. Pełni on także rolę strażnika doktryny katolickiej i przewodnika ludu, aby nie ulegał fałszywej nauce: jest również gwarantem nienaruszalności depozytu wiary. Prezbiterzy zaś powinni być „,zestrojeni z biskupem jak struny z cytrą" 45 .

Bardziej szczegółowe wskazania podaje Ignacy odnośnie do zadań biskupa w dziedzinie liturgii. On jest głównym liturgiem Kościoła ${ }^{46}$. Wymaga, aby bez jego wiedzy, czy nawet zgody chrześcijanie nie zawierali małżeństwa, nie udzielali chrztu ani nie sprawowali agapy ${ }^{47}$; on zwołuje także wiernych na sprawowanie Eucharystii i tylko taką Eucharystię należy uważać za „ważną”, która sprawowana jest pod przewodnictwem biskupa, lub tego, komu on zleci ${ }^{48}$. Należy zauważyć, że w żadnym liście Ignacy nie wspomina o władzy biskupa do udzielania święceń. Być może dlatego, że w tym czasie nikt nie kwestionował tego wyłącznego prawa biskupa.

Biskup i prezbiterzy stanowią kolegium, czyli jedno prezbiterium złączone z biskupem. Tak jak Apostołowie byli poddani Chrystusowi i Ojcu i Duchowi i stanowili jakby radę Boga, tak też prezbiterzy zastępują wiernym radę Apostołów, od wiernych zaś wymaga się posłuszeństwa prezbiterom niby Apostołom Jezusa Chrystusa ${ }^{49}$.

Jeśli chodzi o zadania prezbiterów w ich relacji do Biskupa, Ignacy nie podaje konkretnych przykładów. Na pewno doradzali biskupowi w kierowaniu i wspomagali go w nauczaniu, spełniali jakąś rolę w sprawowaniu Eucharystii, której przewodniczył biskup:

„Jedno bowiem jest Ciało Pana naszego Jezusa Chrystusa i jeden jest kielich, by nas zjednoczyć z Krwią Jego, jeden ołtarz, jak też jeden biskup razem z prezbiterami i diakonami [...]. Starajcie się mieć tylko jedną Eucharystię. Jedno tylko jest Ciało Pana naszego Jezusa Chrystusa i jeden tylko kielich, którym jednoczymy się

\footnotetext{
42 Por. Epistola ad Philadelphios 4, 1.

43 Por. Epistola ad Trallianos 7, 2.

44 Por. Epistola ad Ephesios 2, 2; 20, 2; Ad Magnesios 7, 1; Ad Smyrnenses 8, 1.

45 Epistola ad Ephesios 4, 1, SCh 10, 60, BOK 10, 174.

46 Por. Ihnatowicz, Biskup widzialny i biskup niewidzialny. s. 71.

47 Por. Epistola ad Polycarpum 5, 2; Ad Smyrnenses 8, 2.

48 Por. Ad Smyrnenses 8, 1; Ad Ephesios 13, 1.

${ }^{49}$ Por. Epistola ad Magnesios 13, 2; 16, 1; Ad Trallianos 2, 2.
} 
z Krwią Jego, i jeden tylko ołtarz ofiarny, a więc tylko jeden biskup, otoczony prezbiterami i diakonami, współsługami moimi”50.

Wzmianka o zlecaniu przez biskupa sprawowania „ważnej” Eucharystii odnosi się prawdopodobnie do prezbiterów, którzy przewodniczyli jej z polecenia i w zastępstwie biskupa.

Wierni winni są posłuszeństwo biskupowi, w którym wyraża się przynależność do Boga; jest ono również prawdziwym naśladowaniem Chrystusa w Jego posłuszeństwie $\mathrm{Ojcu}^{51}$. Wierni mają również pozostawać w jedności z jego pomocnikami:
„,...] trzymajcie się biskupa, prezbiterów i diakonów [...]. To Duch mi podszepnął, mówiąc: bez biskupa nic nie czyńcie, ciała swego strzeżcie niby świątyni Bożej, miłujcie jedność, unikajcie rozłamów, naśladujcie Jezusa Chrystusa tak, jak On naśladował swego Ojca" ${ }^{52}$.

Ignacy odróżnia zadania biskupa i prezbiterów. Biskup jest posłany przez Chrystusa Gospodarza jako włodarz, dlatego powinien być przez wiernych przyjęty: „Na biskupa musimy patrzeć jak na samego Pana” ${ }^{, 53}$. W biskupach trwa misja Apostołów, a ich rola podobna jest do roli samego Chrystusa. Jak

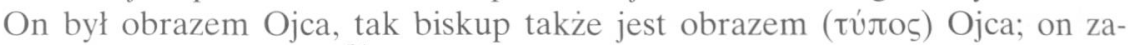
stępuje wiernym Boga ${ }^{54}$. Dlatego posłuszeństwo biskupowi jest posłuszeństwem Bogu, trwanie przy biskupie, jest trwaniem przy Chrystusie: „gdzie się pojawi biskup, niech tam będzie wspólnota tak, jak gdzie jest Chrystus, tam jest Kościół powszechny"55. Posłuszeństwo biskupowi jest naśladowaniem Chrystusa:

„,[..] wszyscy idźcie za biskupem, jak Jezus Chrystus za Ojcem”,56; ,„[..] bądźcie poddani biskupowi i sobie wzajemnie jak Jezus Chrystus według ciała był poddany Ojcu" ${ }^{57} ;$, , [... jak Pan nic nie czynił bez Ojca, tak wy nie róbcie niczego bez biskupa i prezbiterów" 58 .

Dlatego wszyscy, którzy „należą do Boga i Jezusa Chrystusa, są z biskupem”59. Biskup jest dla swego Kościoła jakby „sakramentem” jedności z Bogiem:

${ }^{50}$ Epistola ad Philadelphios 4, SCh 10, 122, BOK 10, 133.

51 Por. Epistola ad Philadelphios 3, 2; Ad Smyrnenses 8, 1; Ad Magnesios13, 2.

52 Epistola ad Philadelphios 7, SCh 10, 126, BOK 10, 134.

53 Epistola ad Ephesios 6, 1, SCh 10, 62, BOK 10, 114.

54 Por. Epistola ad Trallianos 3, 1; Ad Magnesios 6, 1.

55 Epistola ad Smyrnenses 8, 2, SCh 10, 138, BOK 10, 138; por. Ad Ephesios 5, 3; Ad Magnesios 3, 1.

56 Epistola ad Smyrnenses 8, 1, SCh 10, 138, BOK 10, 138.

57 Epistola ad Magnesios 13, 2, SCh 10, 90, BOK 10, 123.

58 Tamże 7, 1, SCh 10, 84, BOK 10, 121.

59 Por. Epistola ad Philadelphios 8, 2. 
„[...] starajcie się wszystko czynić w zgodzie Bożej pod kierunkiem biskupa, który zastępuje wam Boga, prezbiterów zastępujących radę Apostołów i moich najdroższych diakonów, mających udział w posłudze Jezusa Chrystusa"60.

Miejsce biskupa w Kościele i jego autorytet są gwarancją jedności i ortodoksji:

„Niech nikt w sprawach dotyczących Kościoła nie robi niczego bez biskupa. Uważajcie za ważną tylko taką Eucharystię, która sprawowana jest pod przewodnictwem biskupa lub tego, komu zleci"61.

Jedność biskupa z Bogiem jest fundamentem wspólnoty prezbiterów i diakonów z biskupem, a harmonia w Kościele lokalnym jest z kolei gwarantem harmonii pomiędzy wszystkimi Kościołami. Jedność z biskupem oznacza więc jedność z Bogiem.

Ignacy Antiocheński uważa prezbiterów za następców Apostołów, mających udział w posłudze słowa i sakramentów; razem z diakonami wspierają oni biskupa. Nie wiadomo dokładnie, jakie funkcje pełnili na co dzień. Z listów Ignacego wynika, że biskup zlecał im sprawowanie sakramentów i inne posługi.

Diakoni należeli do hierarchii Kościoła i nie tylko posługiwali stołom:

„Trzeba też, aby i diakoni, będący sługami tajemnic Jezusa Chrystusa podobali się wszystkim na wszelki sposób. Nie są bowiem usługującymi przy jedzeniu i piciu, lecz sługami Kościoła Bożego" ${ }^{2}$.

Ignacy nie wspomina o roli diakona w liturgii, tej bowiem przewodniczy zawsze biskup, a czasem w jego zastępstwie prezbiter: prezbiterzy i diakoni razem z biskupem są w służbie Kościoła.

$\mathrm{Z}$ listów Ignacego wynika, że nie ma istotnej różnicy między prezbiterami i biskupami, Kościół zaś początkowo kierowany był przez prezbiterów, z których następnie wybierano biskupa. Tym, co różni prezbitera od biskupa jest tylko to, że biskup udziela święceń, czego nie może czynić prezbiter, co później wyraźnie podkreśli św. Hieronim:

„Cóż bowiem, prócz udzielania święceń, czyni biskup, czego nie może czynić prezbiter"63.

Na podstawie listów św. Ignacego można zatem ukazać biskupa-prezbitera jako ojca, pasterza i strażnika. Prowadzi on i czuwa nad domus Ecclesiae jednocząc wszystkich członków wspólnoty, troszczy się o potrzebujących, biednych, wdowy, niewolników, o dobra duchowe i doczesne. Określenie „pasterz”

${ }^{60}$ Epistola ad Magnesios 6, 1, SCh 10, 84, BOK 10, 121; por. także Ad Smyrnenses 8, 1; Ad Philadelphios 3,1.

61 Epistola ad Smyrnenses 8, 1, SCh 10, 138, BOK 10, 138.

62 Epistola ad Trallianos 2, 3, SCh 10, 96, BOK 10, 124.

${ }^{63}$ Hieronymus, Epistola 146, 1, PL 22, 1193, thum. J, Czuj, III, Warszawa 1954, 431. 
nawiązuje do J 10, a jego głównym zadaniem jest czuwanie nad jednością owczarni, aby wszyscy gromadzili się wokół biskupa. Biskup jako pasterz przewodniczy Eucharystii, bo w niej jest miłość Chrystusa, a wspólnotę tworzy także miłość-agape. Pasterz winien być gotowy oddać życie za swoje owce. Jak okręt wymaga sternika posiadającego umiejętność kierowania i dowodzenia dla bezpieczeństwa i dobra podróżujących, tak samo Kościół musi mieć sterni$\mathrm{ka}$, aby bezpiecznie prowadził wiernych do Boga ${ }^{64}$.

4. Św. Polikarp († 155). Uczeń św. Jana Apostoła, biskup Smyrny, we wstępie Listu do Filipian pisał: „Polikarp, wraz z prezbiterami, do Kościoła Bożego, który pielgrzymuje w Filippi”. Wspominał także diakonów stawiając im konkretne wymagania:

„[...] diakoni niech będą bez zarzutu w obliczu Jego sprawiedliwości, jako słudzy Boga i Chrystusa, a nie ludzi. Niech nie będą oszczercami, obłudnymi, chciwymi, ale we wszystkim umiarkowani, miłosierni, troskliwi, naśladujący wiernie Pana, który stał się sługą wszystkich"

Podobnie poucza prezbiterów:

„Prezbiterzy niech będą współczujący i miłosierni wobec każdego, niech przywołują błądzących, odwiedzają wszystkich chorych, niech nie zaniedbują wdów, sierot i ubogich, ale niech «starają się zawsze czynić dobro przed Bogiem i ludźmi». Niech się powstrzymują od wszelkiego gniewu, unikają stronniczości, niesprawiedliwego sądu, niech wystrzegają się pilnie wszelkiej chciwości, niech nie przyjmują łatwo oskarżeń i niech nie będą zbyt surowi w osądzaniu, pamiętając, ze wszyscy podlegamy grzechowi" ${ }^{\prime 6}$.

W liście tym Polikarp poświadcza, że w Kościele działa razem z prezbiterami, napomina ich jako przełożony i ojciec oraz poświadcza istnienie diakonów określając ich kwalifikacje moralne oraz zadania we wspólnocie.

5. Św. Klemens Aleksandryjski († przed 215). Według Klemensa Aleksandryjskiego o tym, czy ktoś jest rzeczywistym prezbiterem decyduje nie sama ordinatio i przynależność do rady starszych - prezbiterium, ale to, czy wypełnia i wykłada przykazania Boże. Prezbiterem jest ten, kto czyni i naucza tego, co Pan nakazuje ${ }^{67}$. Wylicza także stopnie hierarchiczne: biskupów, prezbiterów i diakonów ${ }^{68}$. Kościelne stopnie hierarchii, odpowiadają niebieskiej hierarchii.

${ }^{64}$ Por. Hamman, Kaptan w II wieku s. 51-53.

65 Polycarpus, Epistola ad Philippenses 5, 2, SCh 10, 216, BOK 10, 158.

66 Tamże 6, 1, SCh 10, 216, BOK 10, 158.

${ }^{67}$ Por. P. Szczur, Urząd prezbitera w świetle pism Klemensa z Aleksandrii, RT 51 (2004) z. 4, 68-69.

68 Por. Clemens Alexandrinus, Stromata VI 107, 2-3; Szczur, Urząd prezbitera, s. 72-77. 
Prezbiter był wybierany przez ludzi, był członkiem rady starszych - prezbiterium, urzędy zaś biskupa, prezbitera i diakona były otaczane szacunkiem. Prezbiterzy trudzą się, aby doskonalić wiernych, diakoni służą im pomocą w tym dziele. Prezbiterzy byli także zwierzchnikami diakonów, mieli pomagać w poprawie życia wiernych, udzielali błogosławieństwa wiernym przez nałożenie rąk. Na urząd biskupa, prezbitera i diakona należy wybierać ludzi z grupy gnostyków.

6. Św. Cyprian († 258). Biskup Kartaginy pisze często w swoich listach o prezbiterach i diakonach, którzy pod jego nieobecność mają kierować Kościołem $^{69}$. Razem z nim prezbiterzy tworzą prezbiterium ${ }^{70}$, nazywa ich conpresbyteri $^{71}$ i nierzadko wymienia w adresie listów razem z biskupami. Oznacza to, że prezbiterzy posiadają wspólnie z biskupem sacerdotalis honor ${ }^{72}$. Odnosi się to nie tylko do liturgii, bowiem prezbiterzy są także praepositi i praesidentes jako stojący na czele gminy. Słowo „honor” znaczy tu nie tyle cześć, co urząd. Urząd biskupa jest $\mathrm{z}$ ustanowienia samego Pana:

„Jeden jest Bóg i Chrystus jest jeden. Jeden jest Kościół i jedna jest stolica, na Piotrze założona, głosem Pana"73.

Cyprian nie używa terminu pontifex, gdyż wtedy jeszcze miał on zabarwienie pogańskie ${ }^{74}$. To, co odnosi się do Apostołów, odnosi się także do biskupa ${ }^{75}$ jako fundamentu Kościoła. Jak jest jeden Bóg i jeden Kościół, tak w Kościele jest jeden biskup stojący na jego czele wspólnoty wiernych ${ }^{76}$ : kto jest w jedności $\mathrm{z}$ biskupem, jest w jedności $\mathrm{z}$ Kościołem ${ }^{77}$. Do biskupa należy kierowanie Kościołem $^{78}$, którego też nazywa pastor, gubernator, rector - a więc tytułami wskazującymi na funkcję kierowniczą w Kościele, oraz sacerdos i praepositus. Zamiennie używa określeń sacerdos, episcopus i praepositus. Diakonom przypomina:

„Apostołów, to jest biskupów i zwierzchników (id est episcopos et praepositos) wybrał Pan (Dominus elegit): diakonów zaś powołali Apostołowie na sługi swego episkopatu i Kościoła"79.

69 Por. Epistola 14, 2.

${ }^{70}$ Por. Epistola 59, 19.

71 Por. Epistolae 14, 4; 4, 24.

72 Por. Epistola 61, 3.

${ }^{73}$ Epistola 43, 5, 2, CCL 3B, 205: „Deus unus est et Christus unus et una ecclesia et cathedra una super Petrum Domini voce fundata", thum. W. Szołdrski, PSP 1, 122.

74 Por. J. Colson, L'évêque lien d'unité et de charité chez saint Cyprien de Carthage, Paris 1961, 26.

75 Por. Cyprianus, Epistola 33, 1.

${ }^{76}$ Por. Epistola 43, 5.

77 Por. Epistola 66, 8 .

${ }^{78}$ Por. Epistola $72,3$.

79 Epistola 3, 3, 1, CCL 3B, 14, PSP 1, 32. 
Cytując słowa Jezusa do Piotra, o jego władzy wiązania i rozwiązywania (Mt 16, 18). Cyprian pisze:

„Wprawdzie zmieniają się czasy i sprawujący urzędy, ale trwa nieustannie ustanawianie biskupów (episcoporum ordinatio) i zarząd Kościoła tak, że Kościół opiera się na biskupach i wszystkie sprawy kościelne przez tych zwierzchników (praepositos) są załatwiane" ${ }^{\prime 0}$.

Biskup jest nierozerwalnie związany z Kościołem, a kto jest w jedności z biskupem, jest także w jedności z Kościołem:

„,[...] biskup jest w Kościele, a Kościół w biskupie i jeśli kto nie jest $\mathrm{z}$ biskupem, nie jest w Kościele" $"$.

Kto sprzeciwia się biskupowi, jest przeciwko Chrystusowi. W biskupie bowiem:

„,[...] trzoda otrzymała pasterza, statek sternika, który by nim kierował, a ludowi został zwrócony zwierzchnik, który by nim rządził" ${ }^{2}$.

W Kościele są także akolici ${ }^{83}$, subdiakoni ${ }^{84}$, lektorzy ${ }^{85}$ i egzorcyści $^{86}$. Cyprian pisze listy adresowane do prezbiterów i diakonów, co oznacza, że oni razem kierują wspólnotą wiernych ${ }^{87}$, wspomina także o wynoszeniu akolitów do godności prezbiteratu $^{88}$.

Według Cypriana do zadań biskupa, poza przewodniczeniem Eucharystii ${ }^{89}$, należy: głoszenie słowa Bożego ${ }^{90}$, udzielanie chrztu ${ }^{91}$, jednanie grzeszników i ustanawianie urzędów w Kościele ${ }^{93}$. Pomocnikami biskupa są prezbiterzy i diakoni. Prezbiterzy służą radą biskupowi ${ }^{94}$, i przewodniczą również Eucharystii $^{95}$, nie tylko wyjątkowo i na polecenie biskupa. Razem z nim wkładają ręce na grzeszników, aby ich pojednać z Bogiem i Kościołem, a jeśli nie ma biskupa, czynią to sami ${ }^{96}$; termin sacerdos u Cypriana oznacza biskupa, najczęściej w związku ze sprawowaniem Eucharystii. On zwykle przewodniczy Eucharys-

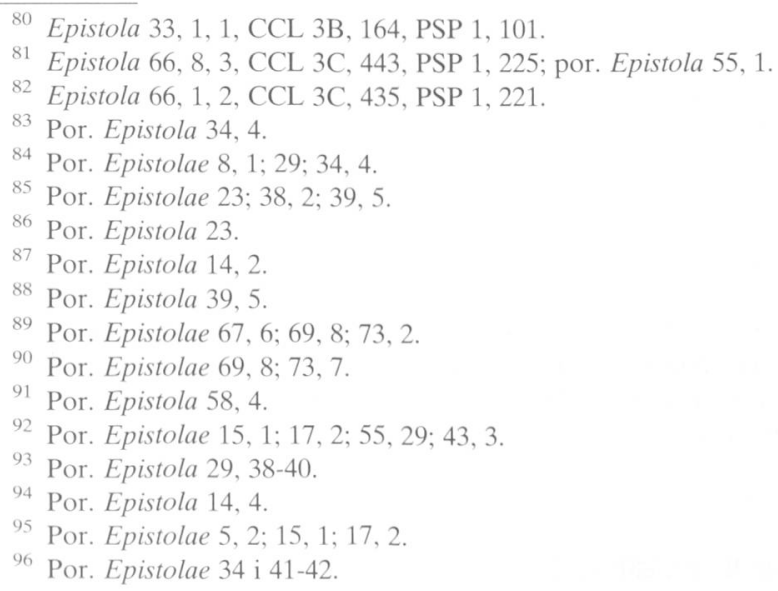


tii, w czasie której prezbiterzy wkładają ręce, diakoni przynoszą dary i pomagają udzielać Komunii św. wiernym.

Cyprian nie pisze nigdzie o diakonach jako stojących na czele wspólnoty. Występują oni zawsze z biskupem lub z prezbiterami. W nieobecności prezbiterów, grzesznik przed nimi może wyznać swoją winę i zostać włączony do Kościoła $^{97}$. O ile prezbiterzy są razem z biskupem (conpresbyteri), to diakoni określani są jako słudzy urzędu biskupa i Kościoła:

„Diakoni powinni pamiętać, że Apostołów tj. biskupów i zwierzchników wybrał Pan, diakonów zaś powołali Apostołowie na sługi (ministros) swego episkopatu i Kościoła" $"$.

Diakoni wspomagali w posługiwaniu także prezbiterów ${ }^{99}$. Cyprian upomina Nowacjana, że bez jego pozwolenia i wiedzy uczynił swego pomocnika Felicissimusa diakonem $^{100}$.

Ustanawianie prezbiterów i diakonów jest:

„,[...] z nakazu Bożego, aby kapłan był wybierany w obecności ludu, na oczach wszystkich i był uznany za godnego uzdolnionego zdaniem i świadectwem ogółu [...] ustanawianie prezbiterów winno być podejmowane tylko w porozumieniu z ludem [...]. Apostołowie nie tylko przy ustanawianiu biskupów i prezbiterów, ale i diakonów tego się trzymali" ${ }^{\prime 101}$.

Postępowanie takie tłumaczy tym, by nikt niegodny nie mógł dojść do służby ołtarza lub kapłańskiego urzędu ${ }^{102}$.

Z listów Cypriana wynika, że biskup kieruje Kościołem w tym wszystkim, co dotyczy życia religijnego i dyscypliny kościelnej. Jest on fundamentem Kościoła i tylko w jedności z nim należy się do prawdziwego Kościoła. Biskup jest wybierany prze wspólnotę i kler oraz biskupów właściwej prowincji kościelnej. To on kieruje swoim Kościołem w jedności z kolegium biskupów. Nie jest jednak delegatem wspólnoty, lecz powołany jest przez Boga. Upomina też diakonów, aby pamiętali, że „Apostołów to jest biskupów i zwierzchników wybrał Pan" (3,3). Przewodniczenie wspólnocie należy także do prezbiterów, którzy tworzą radę biskupa, i dlatego nazywani są conprebyteri jako związani z biskupem w godności i urzędzie kapłańskim (sacerdotalis honor). Prezbiterzy kierują wspólnotą w celebracji Eucharystii i razem z biskupem w jednaniu grzeszników. Biskup jest kontynuatorem posługi apostolskiej i stoi na czele prezbiterium. Diakoni mają zawsze funkcję służebną, tylko w wyjątkowych

97 Por. Epistola 18.

98 Epistola 3, 3, 1, CCL 3B, 14, PSP 1, 32.

99 Por. Epistola 43, 1.

100 Por. Epistola 52, 2.

101 Epistola 67, 4, 1, CCL 3C, 452, PSP 1, 229; por. też Epistola 14, 4, CCL 3B, 83.

102 Por. Epistola 67, 4, 1. 
okolicznościach mogą przewodniczyć i zawsze podlegają biskupowi oraz prezbiterom. Biskupa, prezbiterów i diakonów wybiera cała wspólnota.

7. Hipolit Rzymski († 235). Strukturę hierarchii Kościoła, która występuje w listach św. Cypriana, potwierdza także Hipolit w Tradycji Apostolskiej ${ }^{103}$. Pisze on o tych, którzy mają szczególne zadania we wspólnocie wierzących: biskup, prezbiterzy, diakoni, wyznawcy, wdowy, lektorzy, dziewice i subdiakoni. Biskup jest wybierany przez cały lud i konsekrowany przez kilku innych biskupów przez włożenie ich rąk i modlitwę: przez świecenia zostaje włączony do kolegium Apostołów, dzięki Duchowi Świętemu (Spiritus principalis), który go konsekruje na następcę Apostołów ${ }^{104}$. Odtąd kieruje całą wspólnotą i przewodniczy celebracji Eucharystii. Również prezbiterzy przez włożenie rąk biskupa i innych prezbiterów otrzymują Ducha Świętego, należą do kolegium biskupa i są od niego zależni ${ }^{105}$. Przy święceniach diakona ręce na kandydata

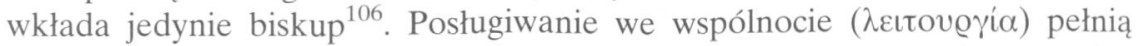
tylko biskupi, prezbiterzy i diakoni. Na nich wkłada się ręce ( $\chi \varepsilon £ \varrho o \tau o v i ́ \alpha)$ i zanosi do Boga modlitwę o dar Ducha Świętego ${ }^{107}$. Biskup jest jak Mojżesz, a prezbiterzy jak grupa 70 starszych, jego współpracowników i doradców. Prezbiterzy są święceni dla kapłaństwa, diakon zaś jest dla służby biskupowi. Te trzy posługiwania tworzą jedność w sprawowaniu sakramentów, w którym współdziałają te trzy typy posług ${ }^{108}$. Diakoni i subdiakoni mieli służyć biskupowi i troszczyć się o chorych: razem z prezbiterami uczestniczyli także w liturgii, której przewodniczył biskup.

8. Orygenes († 253). Terminem gr. į́ॄús - (łac. sacerdos) określa: kapłanów Starego Testamentu, Chrystusa, biskupa, prezbitera i zwykłego ochrzczonego: wszyscy oni uczestniczą w kapłaństwie Chrystusa, ale kapłaństwo wiernych różni się od kapłaństwa tych, którzy pełnią posługiwanie we wspólnocie ${ }^{109}$.

103 Por. Hippolytus Romanus, Traditio Apostolica, ed. B. Botte, SCh 11bis, Paris 1968, thum. H. Paprocki, STV 14 (1976) nr 1, 150-169, lub M. Michalski, ALP I 305-316.

104 Por. tamże 2-4, SCh 11bis, 40-46; zob. też B. Botte, Spiritus Principalis (Formule de l'ordination épiscopale), „Notitiae” 10 (1974) 410-418.

105 Por. tamze 7, SCh 11bis, 56-58.

106 Por. tamże 8, SCh 11bis, 58-62.

107 Por. C. Kogel, L'imposition des mains dans les rites d'ordination en Orient et en Occident, MD 1970, nr 102, 57-72.

108 Por. E. Cattaneo, I ministeri nella Chiesa antica. Testi patristici dei primi tre secoli, Milano 1997, 657-660; J. Colson, La fonction diaconale aux origines de l'Église, Paris - Brugge 1960; J.S. Bojarski, Miejsce i rola diakona w społeczności chrześcijańskiej na podstawie „Didaskalia Apostolorum", STV 9 (1971) 225-262; B. Domagalski, Diakoni rzymscy w IV wieku. Z historii związów biskupa, diakona i prezbitera, VoxP 9 (1989) z. 17, 637-654; M. Górski, Diakonat w starożytnym prawodawstwie kościelnym (III-IX w.), tamże, s. 707-715.

109 Por. M. Szram, Orygenes o kaptaństwie, VoxP 13-15 (1993-1995) z. 24-29, 89-99. 
9. Sw. Jan Chryzostom († 407). Jan Chryzostom w następujący sposób wyjaśnia, dlaczego w I Liście św. Pawła do Tymoteusza pomija się prezbiterów, a po biskupie od razu mowa jest o diakonach:

„Niewiele bowiem różni prezbitera od biskupa. Obaj podjęli obowiązek nauczania i obaj przewodniczą Kościołowi, dlatego to, co powiedział o biskupach, odnosi się także do prezbiterów; tylko bowiem we władzy udzielania święceń biskupi górują nad prezbiterami" 110 .

Według św. Jana Chryzostoma kapłaństwo to „godność anielska” i „,anielska służba" ze względu na Eucharystię, bo:

„,[...] stoi tu kapłan, który już nie ogień, ale Ducha Świętego ściąga z nieba, modli się długo, nie żeby ogień spadł z nieba i pochłonął złożone dary, ale żeby spływająca na ofiarę łaska rozpaliła serca wszystkich i uczyniła je jaśniejsze od oczyszczonego w ogniu srebra. Któż, tylko szalony będzie gardził tą tajemnicą [...] [kapłani] otrzymali moc, jakiej nie dał Bóg aniołom ani archaniołom. Nie do nich bowiem powiedział Chrystus: «Cokolwiek zwiążecie na ziemi...» (Mt 18,18)"111.

Kapłani (biskupi, prezbiterzy) są ojcami duchownymi i twórcami życia Bożego w duszach, udzielają chrztu, który czyni innych dziećmi Bożymi. Dlatego ważny jest odpowiedni i ostrożny wybór kandydatów na kapłanów, stawiane im wymagania świętości życia, aby dawali dobry przykład i byli wzorem dla wiernych; mają też mieć odpowiednią wiedzę i mądrość życiową. Ich zaś główna funkcja polega na głoszeniu słowa Bożego (katecheza i kazania), obrona wiary i troska się o ubogich, chorych oraz podróżnych, którym to winni okazywać miłosierdzie ${ }^{112}$.

10. Św. Ambroży († 397). Biskup Mediolanu w licznych swoich adhortacjach kierowanych do biskupów i w traktacie De officiis ministrorum pisze o obowiązkach związanych z posługiwaniem duchownych. Biskup ma przede wszystkim trzymać „ster wiary” powierzonego mu Kościoła i troszczyć się o jego jedność, którą gwarantuje łączność z biskupem Rzymu. Jego funkcja podobna jest do sternika na okręcie, dlatego powinien on posiadać umiejętność kierowania, korzystając z doświadczenia i przykładu innych. Sam powinien wzorowo wypełniać swoje obowiązki i dawać dobry przykład wiernym. Ma także udzielać rad i napomnień. Podstawowym obowiązkiem biskupa jest nauczanie oparte na nauce Chrystusa i zgodne z nauczaniem Kościoła. Według Ambrożego biskup winien być przede wszystkim człowiekiem wiary, służącym

${ }^{110}$ In Epistolam I ad Timotheum hom. 11, 1, PG 62, 553A.

111 De sacerdotio III 4-5, SCh 272, 146-148, tłum. W. Kania, BOK 1, 74; por. W. Kania, Godność $i$ wielkość chrześcijańskiego kaptaństwa wedtug św. Jana Chryzostoma, VoxP 13-15 (1993-1995) z. 24-29, 122-123.

112 Por. Kania, Godność $i$ wielkość chrześcijańskiego kapłaństwa, s. 122-127. 
innym i troszczącym się o ich dobro, zdecydowanym w działaniu w obronie wiary i dobrych obyczajów ${ }^{113}$. Biskupi mają również stać na straży sprawiedliwości społecznej, chronić wdowy i sieroty, oraz ubogich i cudzoziemców ${ }^{114}$.

W swoich listach do kleru wzywał, aby prezbiterzy wyróżniali się wzorowym sposobem życia, posiadali ducha ewangelicznego i kulturę osobistą oraz zajmowali się studiowaniem nauki Kościoła:

„Dlaczego godzin wolnych, jakie ci zostają poza obowiązkami kościelnymi, nie poświęcasz na czytanie?"115.

Wymaga także posłuszeństwa wobec biskupa, a jego brak uważa za grzech:

„Jeśliby ktoś nie był posłuszny biskupowi, [...] ten zbaczając z drogi prawdy, grzeszy pychą" 116 .

Prezbiterzy nie powinni także ubiegać się o godności i zaszczyty.

11. Św. Augustyn († 430). Biskup Hippony pisze o istniejącej różnicy między kapłaństwem wiernych i kapłaństwem ze święceń. Regale sacerdotium jest wspólne ochrzczonym, którzy zostali namaszczeni Duchem Świętym (por. 1P 2, 9) ${ }^{117}$. W Kościele jest jednak także kapłaństwo urzędowe, czyli służebne. Posługę kapłaństwa służebnego określa „ministerium necessarium, sine quo vivere nequeunt" ${ }^{\prime 18}$. Bez tej posługi ludzie nie mogą stać się chrześcijanami, ani żyć jak chrześcijanie ${ }^{119}$. To ministerium w Kościele jest konieczne. Św. Augustyn wyraźnie odróżnia stan duchowny (ordo clericorum) od pozostałych wiernych. Termin zaś sacerdos wyjaśnia w ten sposób: „Ideo sacerdos, quia sacrificium" 120 . Według niego termin sacerdos w sensie właściwym odnosi się jedynie do biskupów i prezbiterów „qui proprie iam vocantur in eccelsia sacerdotes"121; tylko do nich należy składanie ofiar. Włączenie do ordo clericorum dokonuje się poprzez święcenia (ordinatio), które są trzy: biskupstwo, prezbiterat i diakonat, szczytem zaś święceń jest episkopat: „episcopatus pres-

113 Por. J. Pałucki, Swięty Ambroży jako duszpasterz w świetle adhortacji pastoralnych, Lublin 1996, 33-39; K. Gurda, Nauka o kapłaństwie u św. Ambrożego, VoxP 13-15 (1993-1995) z. 24-29, 107-120.

114 Por. Ambrosius, De officiis ministrorum III 9, 59, PL 16, 171, thum. K. Abgarowicz: Św. Ambroży, Obowiazki duchownych, Warszawa 1967, 184.

115 Tamże I 20, 88, PL 16, 54, Abgarowicz, s. 152.

116 Tamże II 24, 122, PL 16, 143, Abgarowicz, s. 152.

117 Por. A. Eckmann, Teologia kapłaństwa w pismach św. Augustyna, VoxP 13-15 (1993-1995) z. 24-29 131-159.

118 Augustinus, Epistola 228, 2, CSEL 57, 485.

119 Por. tamże 228, 4.

${ }^{120}$ Confessiones X 43, 69, CCL 27, 193. Podobnie Izydor z Sewilii (Etymologiae IX 3, 4, PL 82, 342A): „Sicut enim sacerdos a sacrificando, ita rex a legendo”.

121 Augustinus, De civitate Dei XX 10, CCL 48, 720; por. KKK 1591-1592. 
byterio maior sit" ${ }^{122}$, a kto temu zaprzecza, jest w herezji. Biskup stoi na czele Kościoła lokalnego i sprawuje służbę Bożą, głosi słowo i udziela sakramentów. W ogóle biskupi zajmują miejsce Apostołów:

„Dzisiejsi bowiem biskupi ustanowieni po całym świecie skąd się biorą? Sam Kościół nazywa ich ojcami, on sam ich zrodził, sam ustanowił na stolicach ojców. Nie uważaj zatem, że jesteś opuszczony dlatego, że nie widzisz Piotra, że nie widzisz Pawła, ponieważ nie widzisz tych, dzięki którym zostałeś narodzony"123.

Biskupa wspomagają w posługiwaniu zależni od niego prezbiterzy, diakoni zaś pomagają przy udzielaniu Eucharystii. Akolici doręczali listy biskupów, a lektorzy czytali Pismo Święte ${ }^{124}$. Od kandydatów wymagano wysokiego poziomu życia moralnego i wykształcenia: znajomości Pisma Świętego i odpowiedniego wieku.

Augustyn naucza o charakterze sakramentalnym, który trwa stale i nie można go utracić. W De bono coniugali pisze:

„W tych, którzy są wyświęceni (ordinati) pozostaje jednak charakter wyświęcenia (sacramentum ordinationis). A jeśli przez jakąś winę ktoś zostałby odsunięty od tej funkcji, nie zostaje pozbawiony charakteru Pana, raz mu nałożonego (sacramento Domini semel imposito non carebit) ${ }^{\prime 125}$.

Sakramentem tym jest chrzest, ale także ordinatio, jako quaedam consecratio i jako ius dandi. Ordinatio nie ma na celu bezpośrednio własnego zbawienia, lecz jest dla dobra innych. W dyspucie z donatystami twierdzącymi, że do ważności sakramentów konieczna jest świętość szafarza, Augustyn podkreślał, że w sakramentach przez szafarza działa Chrystus, ich skuteczność jest niezależna od świętości szafarza:

„Kogo bowiem Jan (Chrzciciel) ochrzcił, ochrzcił Jan, kogo ochrzcił Judasz, ochrzcił Chrystus. Tak więc tych, których ochrzcił pijak, których ochrzcił zabójca, których ochrzcił cudzołożnik, jeśli był to chrzest Chrystusa, to Chrystus ochrzcił"126.

Św. Augustyn funkcje kapłańskie określał w następujący sposób: „dispensatores verbi et sacramenti - dispesatores verbi Dei et ministri Sacramentorum eius"127. Głoszenie słowa przejawia się w apostolacie, sukcesji biskupiej, jedności nauki i pokoju.

W Starym Testamencie następstwo w posługiwaniu kapłańskim było gwarantowane przez naturalne potomstwo kapłańskiego pokolenia Lewiego.

122 Epistola 82, 4, 33, CSEL 34, 385.

123 Enarrationes In Ps. 44, 32, CCL 38, 516, tłum. J. Sulowski, PSP 38, 182.

124 Por. Epistolae 191, 1; 192; 194, 1.

125 De bono coniugali 24, 32, PL 40, 394, tłum. W. Eborowicz: Wartości matżeństwa, w: Pisma św. Augustyna o matzeństwie i dziewictwie, red. A. Eckmann, Lublin 2003, 114.

126 In Joannis Evangelium tractatus 5, 18, CCL 36, 51-52, thum. W. Szołdrski, PSP 15/1, 93.

127 Sermo 351, 3, 5, PL 38, 1540. 
W Kościele zaś decyduje nie pochodzenie rodowe, ale boski wybór: Bóg sam powołuje spośród ludu szafarzy swoich tajemnic. Głównym zadaniem szafarzy jest podtrzymywanie zdrowej nauki, troska o jej jedność (unitas doctrinae) i pokój Kościoła (pax Ecclesiae). Kapłan ma ius dandi, jest dispensator sacramenti - przez święte znaki działa przez niego Chrystus, przez niego sam Chrystus chrzci i działa w Eucharystii oraz składa ofiarę ${ }^{128}$.

W świetle pism Ojców Kościoła od początku istnienia wspólnot chrześcijańskich na ich czele stali najpierw Apostołowie, a następnie ustanawiani przez nich przełożeni gminy: episcopi i/lub presbyteri, zależnie od miejscowej tradycji. Biskup razem z prezbiterami, tworzącymi jego radę, oraz diakonami stanowili jedno prezbiterium, w którym funkcja kierownicza należała do biskupa. Posługiwanie biskupa i prezbiterów obejmowało głównie głoszenie Ewangelii, celebrację liturgii oraz kierowanie życiem miejscowej wspólnoty. Diakoni i inni, należący do tzw. kleru niższego, pełnili funkcje służebne wobec biskupa i wspólnoty.

\section{IL MINISTERO DI VESCOVI, PRESBITERI E DIACONI NEGLI SCRITTI DI PADRI DELLA CHIESA FINO AL V SECOLO}

(Riassunto)

L'autore di quest'articolo richiama la nostra attenzione sulla terminologia che si usava per descrivere il servizio dei superiori istituiti dagli Apostoli nelle prime comunità cristiane: episcopi, presbiteri, diaconi, praepositi. All'inizio non si usavano le parole hiereus e sacerdos. Tale terminologia appare già in Didache e, poi, negli scritti dei Padri della Chiesa sia nell'Oriente che nell'Occidente: da Clemente Romano, Ignazio da Antiochia, Policarpo, Clemente d'Alessandria, Cipriano, Ippolito Romano, Origene, Giovanni Crisostomo, Ambrogio, Agostino. Il servizio di „superiori della Chiesa" consisteva nella predicazione del Vangelo, nella celebrazione di liturgie e nella guida di tutta la vita religiosa della comunità e di disciplina secondo le regole della Chiesa. In questo periodo si forma l'ordo clericorum nel quale si entrava tramite l'ordinazione (ordinatio episcopi, presbiteri, diaconi). Con i vescovi che erano al giuda delle Chiese locali, nell'adempimento alla loro missione, collaboravano presbiteri e diaconi, formando il consiglio ecclesiale. I chierici di gradi inferiori (ordines minores) erano al servizio di vescovi e di tutta la comunità dei credenti.

128 Por. De civitate Dei XXII 8, CCL 48, 820: „Episcopus vel presbyter, qui offert”. 